\title{
EMPLOYMENT TRAJECTORIES OF PRERETIREES IN THE CONTEXT OF RETIREMENT-AGE INCREASE
}

Igor Y. KISELEV, Dr. Sc. (Sociology), professor, head of department (igkisselev@mail.ru); Natalia V. OVCHINNIKOVA, Cand. Sc. (Sociology), associate professor (nv.lyusina@yandex.ru); Anna G. SMIRNOVA, Cand. Sc. (Politics), associate professor (agsmirnova2001@mail.ru); YOU MIN, postgraduate student (261747567@qq.com). They are all from the Department of Sociology, P.G. Demidov Yaroslavl State University, Yaroslavl, Russia

\begin{abstract}
The article presents the results of sociological research of employment trajectories of preretirement age workers (preretirees) under the conditions of retirement-age increase. The data obtained allowed us to conclude that these workers implement five employment trajectories: active change, maintenance of the status quo, forced change, refusal to change. A separate group consists of 'undecideds' - respondents who have no strategy for adapting to the pension reform. It was found that $21 \%$ of respondents implement trajectories of active and forced changes aimed at maintaining a job, including through participation in vocational training programs for citizens of preretirement age. At the same time, the majority of respondents (58.5\%) perceive the increase in the retirement age mainly in terms of losses and choose the trajectory of refusal to changes. The factors influencing the choice of employment trajectory were revealed. It has been found that the readiness for active change is demonstrated by the respondents who intend to continue working after retirement age and are informed about the details of the pension reform. Mostly preretirees belonging to the categories of 'managers' and 'specialists' employed in medicine and social services, education, professional, scientific and technical activities implement employment trajectories involving active and forced changes.

Keywords: citizens of preretirement age $\bullet$ retirement-age increase $\bullet$ employment trajectories

DOI: $10.31857 /$ S013216250016776-6

This article is a translation of: Киселев И.Ю., Овчинникова Н.В., Смирнова А.Г., Минь Ю. Траектория занятости предпенсионеров в условиях повышения пенсионного возраста // Sotsiologicheskie Issledovaniia. 2021. No 7: 40-49. DOI: 10.31857/ S013216250012149-6
\end{abstract}

Introduction. The problem of retirement-age increase and comprehending the socioeconomic and political consequences of such a reform is relevant for a number of countries [Domonkos, 2015; Hess, 2017]. Since January 1, 2019, these changes have also affected Russia. For men the retirement age now comes at 65, for women - at 60. As consequently, Russians are forced to adapt to the changing socioeconomic conditions and take into account a number of risks associated with a later retirement. According to a survey conducted by the Public Opinion Foundation in 2018, Russians were therefore concerned about the loss of their retirement savings due to death before they reached retirement age $(39 \%)$, difficulties in finding a job $(10 \%)$, reduced ability to work $(9 \%)$, and deterioration of health $(7 \%)^{1}$.

In the short term, the changes affected primarily citizens of preretirement age. According to Federal Law No. 350-Ф3, the preretirement age comes five years before the age of entitlement to an insurance pension, including early retirement.

The social community in question occupies a special place in the labor market.

${ }^{1}$ Retirement-age increase: citizens' reactions on the decision to raise pensions and its impact on their attitudes toward the authorities. URL: https://fom.ru/Ekonomika/14057 (accessed: May 07, 2021). 
The unemployment rate among the citizens of preretirement age is lower compared to other age groups. According to Rosstat, in 2019 the number of the unemployed in the preretirement age (50-54 years) was $8.8 \%$ of the total number of the unemployed; $55-69$ years $6.8 \%$; in the early retirement age 60-64 years $-2.2 \%$ [Workforce..., 2020: 114]. However, according to experts, behind the outwardly favorable statistics, there is no high demand for the citizens of preretirement and early retirement age at the labor market. As M. Ivanova, A. Balayev and Ye. Gurvich note, employees over the age of 50 often immediately switch from the category of employed to the category of 'inactive', bypassing the state of unemployment [Ivanova et al., 2017]. As a result, representatives of these age groups often find themselves in a situation where they would be ready to continue their employment, but have to leave the labor market because they cannot find a job.

Difficulties are caused by the fact that employers are not ready to employ 'aged' employees. Thus, according to a study conducted by the Institute of Socioeconomic Problems of Population of the Russian Academy of Sciences (RAS) in 2017 and 2018, preretirees accounted for a noticeable share of those who applied to the employment service. At the same time, the majority of applications $(56 \%)$ are related to their inability to find a job on their own [Alexandrova, 2020: 108]. In addition, they easily lose their jobs, being 'the first candidates for dismissal in the case of downsizing, reorganization, and liquidation of an enterprise' [Alexandrova, 2020: 108,109].

Fears of job loss increase during economic crises. The results of studies by the RAS Institute of Sociology show that the effects of the economic crisis of 2014-2016 in Russia affected most of all middle-aged and older people, including preretirees, who faced so-called stagnant unemployment [Russian society..., 2017: 373] and felt the deterioration of their financial situation [Ibid.: 63]. In addition, the group of respondents aged 51-60 years had the highest proportion of pessimists, who are not confident in their future or the future of their country (16\%) [lbid: 317].

The coronavirus pandemic, the ensuing economic downturn and unemployment have contributed to heightened concern among this group. According to the data obtained by the Public Opinion Foundation as part of the CoronaFOM research project, workers in the older age group (46-60 years old), including preretirees, were more likely than others to express concern about the possible loss of their jobs ${ }^{2}$.

The status of preretirees as a 'socially vulnerable group' [Vasilyeva, Nikolayenko, 2020: 148] necessitated the development of special social support measures, aimed at mitigating the risks they face on the labor market under the conditions of the pension reform. The national project 'Older Generation' has been developed as part of the national 'Demography' project. The content of the project envisages a number of measures for professional training and additional professional education of persons of preretirement age. In addition, measures are envisaged, to enable representatives of the older generation to realize their professional potential (e.g. The 'Skills of the Wise' professional skills championship for people over fifty, held according to WorldSkills standards, the All-Russian Forum 'Mentor').

Under subjectively assessed opportunities and risks, citizens of preretirement age have to plan their employment trajectories so as to remain in the labor market longer, depending on the year of retirement. In fact, they will have to determine whether they will choose to work after retirement? Will they take any steps to stay employed? Which ones? Are they committed to retraining, learning new job competencies or a new profession? Are they ready to take advantage of the right granted to citizens of preretirement age to undergo vocational training, including as part of employment assistance programs?

${ }^{2}$ Russians speak out about their labor prospects in January. How have the shares of those who fear of losing their jobs and employment income. February 26, 2021. URL: https://covid19.fom.ru/post/rossiyaneosvoih-trudovyh-perspektivah-v-yanvare (accessed: May 05, 2021). 
The trajectory of employment in the study is understood as a sequence of positions (availability of work / loss of work, work by profession / change of profession, work at the same place / change of work, etc.) that an individual occupies in the professional sphere in the context of socioeconomic transformations caused by the pension reform.

In this regard, the sociological study aims to describe the employment trajectories chosen by the citizens of preretirement age in terms of adaptation to the changed socioeconomic conditions in connection with later retirement, and to identify the factors that determine the choice of employment trajectories.

Research Methodology. To study the employment trajectories of pre-retirees in the period from November 1 to December 1, 2019 the staff of the Sociology Department of the P.G. Demidov Yaroslavl State University conducted a sociological study by questioning, using quota sampling, taking into account the gender and age of respondents. The research involved able-bodied citizens of preretirement age - residents of the Yaroslavl region. 696 people were interviewed: 354 women aged $50-55$ years and 342 men aged $55-60$ years ${ }^{3}$.

The majority of respondents (91.4\%) had a job, $8.6 \%$ did not work at the time of the survey. $46.1 \%$ had higher education. Respondents are mostly engaged in the following areas of economic activity: 'wholesale and retail trade; repair of motor vehicles and motorcycles' $15 \%$; 'education' - 13.6\%; 'manufacturing' - 13.2\%; 'professional, scientific and technical activities' $-12.2 \%$; 'administrative activities and related additional services' $-11 \%$; 'transportation and storage' $-9.2 \%$; 'activities in the field of healthcare and social services' $-8.2 \%$. Among the employed the majority belonged to the category of specialists $(42.1 \%)$ and workers $(33.1 \%)$. Managers make up $14.4 \%$ of respondents; employees, $9.2 \%$; self-employed, $0.7 \%$; and entrepreneurs, $0.5 \%$.

The author's questionnaire included the following blocks of meaning: the first block of questions aimed to identify attitudes toward retirement-age increase, the second - to determine employment trajectories; the third was intended to identify awareness of the rights and benefits for preretirees, the fourth - awareness of measures to promote employment in the national project 'Demography'.

Mathematical and statistical processing of the survey data was performed using IBM SPSS Statistics 25 by compiling frequency distributions and contingency tables using nonparametric statistical criterion $\chi^{2}$ Pearson's criterion.

Employment trajectories of citizens of preretirement age. In order to solve the above tasks, we made a classification of the employment trajectories of the preretirement age citizens. Let us describe the grounds for the classification.

The first ground reflects the willingness of respondents to make efforts to keep their jobs for the long term ${ }^{4}$. The second basis reveals the list of measures that respondents take to keep their jobs in the face of an increase in the retirement age. Thus, differentiated are the attitudes, on the one hand, for the acquisition of fundamentally new competencies by receiving another education or undergoing professional retraining. On the other hand, the measures that allow increasing the level of competence within the existing profession through advanced training, high quality performance of their duties, career development are highlighted ${ }^{5}$. The third ground is the participation of respondents in professional training programs for citizens of preretirement age ${ }^{6}$. It was introduced in order to avoid possible bias in the results due to the fact that for a number of professions advanced training is a necessary requirement.

${ }^{3}$ Data from the 2010 All-Russian Population Census for Yaroslavl Region were used to calculate the quotas.

${ }^{4}$ This willingness was determined on the basis of responses to the question, 'Are you doing anything right now to keep your job for the long term and have an advantage over other candidates for your position?' (closed question)

${ }^{5}$ Analysis of the responses to the semi-closed question, 'What exactly are you doing [to keep your job for the long term and to have an advantage over other candidates for your position]?'

6 'Have you taken part in professional training and additional professional education activities for people of preretirement age?' (closed question). 
Respondents can refer to advanced training within the framework of their professional activity (the second basis of classification) and at the same time take part in vocational training programs for preretirement citizens, considering them as an additional opportunity to keep working under the conditions of increasing retirement age.

Questions to identify mindsets about job retention and participation in vocational training programs for pre-retirees were included in the questionnaire in advance. The respondents' answers on the listed grounds were compared by means of the logical rectangle method (see: [Tatarova, 1999]). The results are presented in Table 1.

Table1

\section{'Logical rectangle' to determine the employment trajectory of citizens of preretirement age}

\begin{tabular}{l|c|l|c|c}
\hline Employment trajectory & $\begin{array}{c}\text { Willingness to } \\
\text { take action to } \\
\text { keep the job }\end{array}$ & Measures to keep the job & $\begin{array}{c}\text { Participation in } \\
\text { vocational train- } \\
\text { ing programs for } \\
\text { preretirees }\end{array}$ & $\%$ \\
\hline 'Active Changes' & Yes & $\begin{array}{l}\text { Professional retraining and/or Get- } \\
\text { ting a new education } \\
\text { Professional development, and/ } \\
\text { or attendance at training pro- } \\
\text { grams and/or career development, } \\
\text { and/or willingness to perform } \\
\text { responsibilities }\end{array}$ & Yes & 13.1 \\
'Maintaining the Status & Yeso' & No & No & 17.1 \\
'Undecideds' & Yes & No & No & 3,4 \\
'Refusal to Changes' & No & No & Yes & 7.9 \\
'Forced Changes' & No &
\end{tabular}

Let's focus on the main characteristics of trajectories. Employees focused on active changes intend to make efforts to keep their job for a long time. In their opinion, keeping a job is possible through professional retraining or getting another education in addition to the main one. They also participated in vocational training programs for citizens of preretirement age. Participation in such programs was often proactive in nature. Thus, $36.4 \%$ of the respondents who chose the trajectory of active changes underwent professional training themselves; another $20.4 \%$ were initiated by the employer, but chose the program themselves.

Note that $45.1 \%$ of those implementing a trajectory of active changes expected vocational training for preretirees to help them keep their jobs or find a new one in case of dismissal. As a result, $22 \%$ affirmed such expectations. Half (50.6\%) of those implementing this trajectory are considering mentoring young employees of the organization or company.

The study participants who have chosen a trajectory aimed at maintaining the status quo, as well as those aimed at active changes, intend to take action to keep their jobs for a long term. However, at the same time, they give preference to measures that allow them to perform their previous work at the same company or organization: to improve their qualifications, to perform their responsibilities in good faith. These respondents did not participate in vocational training programs for preretirees and if they received such an offer from an employer, they declined it (9.7\%). At the same time, $56 \%$ of those adhering to this trajectory would recommend themselves as mentors at their company or organization. Thus, this group of workers is even more interested in acquiring a new status in the organization than supporters of active changes in their employment. We can assume that mentoring allows them to remain employed at their company or organization, to implement their existing professional competencies in their new status.

The third trajectory is implemented by respondents who did not demonstrate an intention to make efforts to keep their job for a long time. Accordingly, they did not take concrete steps in this direction. At the same time, they participated in a professional training program for citizens of preretirement age. It should be noted that the majority $(56.6 \%)$ did it at the 
initiative of the employer. In this connection, the trajectory of such respondents is defined as 'forced change'.

In terms of a number of attitudes this group is close to those who have chosen the trajectory of active changes, this also applies to the positive attitude to the opportunity to act as mentors for young employees of the organization or enterprise (54.5\%). There are also differences. For example, the majority of those who implement the trajectory of forced change $(64.8 \%)$ do not follow the situation on the labor market and the professions in demand. It is possible to draw conclusion that these employees are more likely to adapt under the influence of external circumstances, rather than experience an internal need for change.

The fourth trajectory was defined as a denial of change: the workers who adhered to it did not take action to keep their jobs. Thus, they did not take part in the program of professional training for citizens of preretirement age. At the same time, $7.3 \%$ refused such an offer from their employer, while the rest did not receive it. In addition, these workers do not keep track of what professions are in demand in the labor market (72.6\%). Most of them do not see themselves as mentors for young employees (56.1\%). It is obvious that the measures developed by the state to promote the employment of citizens of preretirement age were not in demand in this group of the employed.

The fifth trajectory is characteristic of those who intend to make efforts to keep their jobs, but do not specify them. We can describe such respondents as 'undecided'. They do not keep track of which professions are most in demand on the labor market (65.2\%). In addition, $41.7 \%$ of them would not want to try themselves as mentors for young employees in an enterprise or organization.

The trajectories we identified were combined into two groups based on the respondents' attitudes toward adapting to the changes associated with the increase in retirement age. The first group included those aimed at keeping a job or searching for a new one in the face of an increase in the retirement age. These included trajectories that involve an orientation toward active change, forced change, and preservation of the status quo.

The second group implies a rejection of changing labor behavior, including within the framework of measures to promote employment of citizens of preretirement age, which are proposed within the framework of the federal project 'The Older Generation'. It constitutes the majority of respondents (61.9\%). The unwillingness of preretirees to significantly adjust employment behavior in order to minimize the risks of job loss is also confirmed by the results of other studies. Thus, O.A. Aleksandrova notes that even when applying to the employment service such workers with 20 and 30 years of work experience are more sensitive than the average in the sample to the offer to work outside their specialty and noticeably more often (at the level of $50 \%$ ) are not ready to retrain in accordance with the offered vacancies [Aleksandrova, 2020: 108].

Such attitudes can be explained in terms of the peculiarities of preretirement labor motivation. According to M.V. Prokhorova and V.M. Prokhorov's research, workers over 50 years old belong to the group of 'career-comers'. Their work motivation is characterized by significantly expressed motives of material reward and avoidance of failure, the desire to avoid criticism and low indicators of the need for self-actualization. At the same time, employees of this age group demonstrate the focus on the work process, promotion [Prokhorova, Prokhorov, 2015: 62-63]. The above features allow us to conclude that preretirees are interested in keeping their jobs. At the same time, they would prefer to avoid situations in which they might experience failures and criticism. Exactly such experiences can arise in the conditions of retraining, mastering of new types of activity, search for a new job.

Thus, at the end of their careers, preretirees predominantly stick to their intention to 'finish their work in peace' at their previous workplace. At the same time, 38.1\% of the respondents implement employment trajectories that imply changes. The explanations related to the peculiarities of labor motivation should be supplemented with an analysis of other factors that 
influence the choice of employment trajectory by the citizens of preretirement age. Let us consider some of them.

Factors in the choice of employment trajectories by the citizens of preretirement age. The respondents' attitude to continue working after retirement age plays a significant role. The differences are statistically significant: $\chi_{(d f=16)}^{2}=49.829 ; p<0.001$. According to the findings, $33.4 \%$ give an affirmative answer to the question whether they intend to continue working after retirement age. However, the distribution of answers differs among respondents implementing different employment trajectories. Most often the intention to continue working is expressed by those who adhere to the trajectory of forced changes $(50.9 \%)$, active changes (47.3\%), and maintaining the status quo (42\%). In turn, only $21.7 \%$ of the undecided and $26 \%$ of those who chose the trajectory of denial of change, would like to continue working after reaching retirement age. Thus, planning a longer career is the reason for choosing an employment trajectory that involves adapting to the changes associated with retirement-age increase, through vocational schools and colleges, and participating in a mentoring program.

The choice of employment trajectory also depends on citizens' awareness of the rights and benefits stipulated by the law on retirement-age increase (see Table 2).

Table 2

Awareness of social support measures for citizens

in the context of retirement-age increase (in \%) of respondents, $N=696$ )

\begin{tabular}{|c|c|c|c|c|c|}
\hline \multirow{2}{*}{$\begin{array}{l}\text { "Did you know } \\
\text { that..." }\end{array}$} & \multirow{2}{*}{$\begin{array}{l}\text { Employment } \\
\text { trajectories }\end{array}$} & \multicolumn{3}{|c|}{ Response options } & \multirow[t]{2}{*}{$x^{2}$} \\
\hline & & $\begin{array}{l}\text { This is the } \\
\text { first time I've } \\
\text { heard of it. }\end{array}$ & $\begin{array}{l}\text { I heard } \\
\text { something. }\end{array}$ & I know & \\
\hline $\begin{array}{l}\text { Citizens of preretire- } \\
\text { ment age are paid } \\
\text { benefits for a long } \\
\text { period of time. }\end{array}$ & $\begin{array}{l}\text { Active changes } \\
\text { Maintaining the sta- } \\
\text { tus quo } \\
\text { Denial of changes } \\
\text { Forced changes } \\
\text { Undecided }\end{array}$ & $\begin{array}{l}38.9 \\
52.1 \\
53.3 \\
25.5 \\
69.6\end{array}$ & $\begin{array}{l}28.9 \\
29.4 \\
31.9 \\
45.5 \\
21.7\end{array}$ & $\begin{array}{l}32.2 \\
18.5 \\
14.8 \\
29 \\
8.7\end{array}$ & $\begin{array}{l}\left.\chi_{(d f}^{2}=8\right)=32.807 \\
p<0.001\end{array}$ \\
\hline $\begin{array}{l}\text { Citizens of preretire- } \\
\text { ment age can be re- } \\
\text { trained at the ex- } \\
\text { pense of the state }\end{array}$ & $\begin{array}{l}\text { Active changes } \\
\text { Maintaining the sta- } \\
\text { tus quo } \\
\text { Denial of changes } \\
\text { Forced changes } \\
\text { Undecided }\end{array}$ & $\begin{array}{c}18.9 \\
26.3 \\
40 \\
25.5 \\
45.8\end{array}$ & $\begin{array}{c}20 \\
34.7 \\
33.6 \\
30.9 \\
29.2\end{array}$ & $\begin{array}{c}61.1 \\
39 \\
26.4 \\
43.6 \\
25\end{array}$ & $\begin{array}{l}\left.\chi_{(d f}^{2}=8\right)=48.214 \\
p<0.001\end{array}$ \\
\hline $\begin{array}{l}\text { Citizens of preretire- } \\
\text { ment age have the } \\
\text { right to be released } \\
\text { from work for two } \\
\text { working days once a } \\
\text { year to undergo med- } \\
\text { ical examinations }\end{array}$ & $\begin{array}{l}\text { Active changes } \\
\text { Maintaining the sta- } \\
\text { tus quo } \\
\text { Denial of changes } \\
\text { Forced changes } \\
\text { Undecided }\end{array}$ & $\begin{array}{l}23.3 \\
33.6 \\
44.3 \\
18.2 \\
37.5\end{array}$ & $\begin{array}{c}12.2 \\
29.4 \\
25.4 \\
18.2 \\
25\end{array}$ & $\begin{array}{c}64.4 \\
37 \\
30.3 \\
63.6 \\
37.5\end{array}$ & $\begin{array}{l}\left.\chi_{(d f}^{2}=8\right)=55.369 \\
p<0.001\end{array}$ \\
\hline
\end{tabular}

So, the respondents who implement trajectories of active and forced change are aware of the fact that they can be trained at the expense of the state. In addition, they are informed about the possibility of obtaining long-term benefits in case of job loss. Those who deny change tend to be less aware of rights and benefits. The differences are statistically significant. Thus, the choice of employment trajectories that do not imply any change in labor behavior in the context of retirement-age increase depends on the fact that the respective respondents are poorly informed about the details of the reform.

Different groups of people (managers, experts, employees, workers) choose different employment trajectories. The differences are statistically significant: $\chi^{2}(\mathrm{df}=12)=31.827$; $\mathrm{p}=0.001$. In all these groups the employment trajectory that implies denial of changes prevails. This trajectory is least often followed by managers and most often by workers. On the contrary, the trajectory of active changes is more often preferred by managers and less often 
by representatives of working professions. The latter do not seek to acquire additional competencies through participation in professional training programs for preretirees. However, if they do receive training, they are acquiring skills to qualify for professional posts (computer skills, accounting, managerial activities, pedagogical activities). Managers, in turn, learn programs in the area of management activities, occupational safety, pedagogics, and computer work.

The trajectory of forced changes is most often implemented by experts $(11.6 \%)$, while active changes are made by $16.6 \%$, the same number of employees choose the trajectory associated with maintaining the status quo. If this group of employees is undergoing professional training for preretirees, then the programs selected are related to the content of activities in areas such as social work, medical practice, accounting, and training. But additional competencies in the field of computer work, management and labor protection can also be mastered. It can be assumed that such a trajectory of employment allows them to retain their previous job and profession through career growth and the acquisition of additional skills.

The choice of employment trajectories by different categories of personnel differs depending on the sphere of economic activity. Thus, those employed in manufacturing industries mostly pursue a strategy of denial of changes $(52.6 \%)$ or seek to maintain the status quo (19.7\%). The minority among them are undecided (5.3\%) and those who implement the strategy of forced changes (9.2\%). At the same time, $13.2 \%$ follow the way of active changes. Differences are statistically significant: $\chi_{(\mathrm{df}=4)}^{2}=52.4 ; \mathrm{p}<0.001$. Thus, preretirees employed in the manufacturing industry tend to pursue a 'cautious' employment strategy that precludes significant changes in the field of professional activity. Moreover, they are more often than others $(46.1 \%)$ ready to recommend themselves as mentors for young employees of enterprises. The choice of such a strategy corresponds to the situation on the labor market. According to the 'Avito. Work' survey, old-age jobseekers are in demand in the heavy industry, and they often occupy vacancies in blue-collar occupations ${ }^{7}$.

Facing no competition from younger workers, preretirees employed in manufacturing industries pursue employment trajectories that do not involve significant change in labor behavior. Those employed in commerce also pursue employment trajectories based primarily on denial of change $(68.8 \%)$ and maintenance of the status quo $(20.9 \%)^{8}$. Similar attitudes are shared by those employed in transportation and storage. A different ratio of employment trajectories is observed among those employed in education, healthcare and social services, professional, scientific and technical activities. A third of respondents tend to follow trajectories that involve active or forced change. Most often they are chosen by employees of healthcare and social services (40.5\%). At the same time, they master competencies related to their main professional activity (medicine and social work), acquire computer skills. Among educators, trajectories associated with active or forced change are implemented by $33.5 \%$ of respondents. Through vocational training programs for preretirees they master competencies in teaching, social work, management, computer work, medical work, and occupational safety. Preretirees working in professional ${ }^{9}$, scientific, and technical activities choose similar attitudes in employment.

A more pronounced attitude to acquire additional competences in the mentioned spheres of activity is explained, among other things, by the need to keep a job in the

${ }^{7}$ Cited from: Na prostorakh Rossiyi [In the vastness of Russia]. ДемоскопWeekly 2019. No. 831-832. URL: http://www.demoscope.ru/ weekly/2019/0831/rossia01.php\#13 (accessed on: June 24, 2020).

${ }^{8}$ One explanation has to do with preretirees taking jobs in Internet commerce. See lbid.

${ }^{9}$ Professional sphere is the sphere of economic activity according to the classifier of types of economic activities, which includes lawyers, accountants, engineers, etc. 
situation of competition on the labor market ${ }^{10}$. The acquisition of additional competences can be regarded by employees as a competitive advantage.

Conclusions. The results of the study suggest that the citizens of preretirement age, irrespective of their sector of employment or socio-professional affiliation, mostly follow employment trajectories that do not imply adaptation to the changes associated with an increase in the retirement age. At the same time, those of them who plan to work after retirement age demonstrate an attitude to adapt to change, including by mastering new professional competencies. Promotion of active employment of preretirees in the media and dissemination of information about the opportunities for preretirees in the current situation both at the level of employers and employment services and at the state level can promote a more active attitude toward adapting to the changes associated with the increase in the retirement age.

The continuous acquisition of new competencies, including through information and communication technologies, mastering online courses becomes an integral part of career building. It is important to understand which professions and corresponding competencies are in demand in the regions and which retraining programs will allow to master them. The results of the study showed that citizens of preretirement age rarely link the possibility of keeping a job or finding a new one with professional retraining. The majority have education and long work experience in their chosen field of professional activity, and retraining as a measure to promote employment looks ineffective. This indicates, among other things, that the proposed retraining programs and their content do not fully correspond to the situation on the labor market. It is important to build such a correspondence and at the same time to take into account the peculiarities of employment of different age groups, not only the citizens of preretirement age in the context of the situation in the regions.

\section{REFERENCES}

Aleksandrova O.A., Predpensionery: perspektivy trudoustroystva na stolichnom rynke truda. Arkhitektura finansov: forsazh-razvitiye ekonomiki v usloviyakh vneshnikh shokov i vnutrennikh protivorechiy. [Employees of Preretirement Age: Perspectives of Employment on the Labor Market of Russian Capital. Architecture of Finances: Forcing Development of Economics in Conditions of External Shocks and Internal Contradictions]. In: Maksimtseva I.A., Gorbashko Ye.A., Shubayeva V.G. (eds). Collected Articles of $X$ Anniversary Theoretical and Practical Conference. SPbGEU, St. Petersburg, 2020, p. 107-110. (In Russ.)

Vasil'yeva Ye.G., Nikolayenko N.A., Kto takiye predpensionery? K voprosu o sotsial'nom statuse gruppy [Who are preretirees? On the question of the social status of the group]. Logos et Praxis. 2020. Vol. 19, No. 1, pp. 147-159. (In Russ.)

Ivanova M., Balayev A., Gurvich Ye., Povysheniye pensionnogo vozrasta i rynok truda [Retirement-age increase and the labor market]. Voprosy ekonomiki, 2017, No. 3, pp. 22-39. (In Russ.)

Prokhorova M.V., Prokhorov V.M. Vozrastnaya dinamika vnutrenney $i$ vneshney motivatsiyi trudovoy deyatel'nosti [Age dynamics of internal and external motivation of labor activity]. Vestnik YUUrGU. Series «Psikhologiya», 2015, Vol. 8, No. 3, pp. 57-64. (In Russ.)

Rabochaya sila, zanyatost' i bezrabotitsa $v$ Rossiyi (po rezul'tatam vyborochnykh obsledovaniy rabochey sily) [Labor force, employment and unemployment in Russia (based on the results of sample labor force surveys)]. 2020. Statistical book. Rosstat, Moscow, 2020. (In Russ.)

Rossiyskoye obshchestvo $i$ vyzovy vremeni [Russian society and the challenges of the time]. Book 5. (Eds.) Gorshkov M.K., Petukhov V.V. Moscow: Ves' Mir Publishers, 2017. (In Russ.)

${ }^{10}$ Thus, as of January 1, 2020, in the Yaroslavl Region, the number of offers on the labor market exceeds the number of open vacancies in the professions related to the types of activities under consideration ('economists', 'legal advisors, lawyers, judges', 'social workers', 'heads of various enterprises and organizations', 'accountants', 'managers'). See: Demand and supply of labor in the labor market by groups of positions and professions as of January 1, 2020. URL: https://www.yarregion.ru/depts/ dgszn/ Pages/\%D0\%9E\%D0\%BF\%D0\%B5\%D1\%80\%20\%D0\%B4\%D0\%B0\%D0\%BD\%D0\%BD\%BD\%D1\%8B\%D0\%B5. aspx (accessed on: March 30, 2021.) 
Tatarova G.G., Metodologiya analiza dannykh v sotsiologiyi (vvedeniye) [Methodology for data analysis in sociology (introduction). NOTA BENE Publishing Group, Moscow, 1999. (In Russ.)

Domonkos S., Promoting a Higher Retirement Age: A Prospect-theoretical Approach. International Journal of Social Welfare, 2015, Vol. 24, No. 2: 133-144.

Hess M., Rising Preferred Retirement Age in Europe - Are Europe's Future Pensioners Adapting to Pension System Reforms? Journal of Aging \& Social Policy, 2017, Vol. 29, No. 3: 245-261. 